\title{
EPISTIMOLOGI MANAJEMEN DI ERA KEMAJUAN ISLAM
}

\author{
Nayyif Sujudi \\ Kepala Departemen Pendayagunaan Baznas Provinsi Jawa Barat \\ Email: nayyifsujudi991@gmail.com \\ Nabil \\ STIT Al Marhalah Al Ulya Bekasi \\ Email: nabil@almarhalah.ac.id
}

\begin{abstract}
In the context of Islam, science is the beginning of human substance in building world civilization. Islamic epistemology has similarities with the term science in Western epistemology. Just as science in Western epistemology is distinguished from knowledge, science in Islamic epistemology is distinguished from opinion (ra'y). Science is not arbitrary knowledge or just opinion, but knowledge that has been tested for truth. The understanding of science is actually not much different from science, only science is limited to physical or sensory fields, science goes beyond it in non-physical fields such as metaphysics. Historical metamorphosis is added to analysis and management knowledge. Muslim philosophers are used as a basic reference as the core paradigm of management based on humanity and human patterns.
\end{abstract}

Keywords: Epistemology, Muslim Philosophers, Islamic Management Orientation

\begin{abstract}
Abstrak
Dalam konteks keislaman, ilmu merupakan awal subtansi manusia dalam membangun peradaban dunia. Epistimologi Islam mempunyai kemiripan dengan istilah science dalam epistimologi Barat. Sebagaimana sains dalam epistimologi Barat dibedakan dengan knowledge, ilmu dalam epistimologi Islam dibedakan dengan opini ( $\left.r a^{\prime} y\right)$. Ilmu bukan sembarangan pengetahuan atau sekedar opini, melainkan pengetahuan yang telah di uji kebenaranya. Pengertian ilmu sebenarnya.tidak jauh berbeda dengan sains, hanya sains dibatasi pada bidangbidang fisik atau indrawi, ilmu melampauinya pada bidang-bidang non fisik seperti metafisika.Metamorfosa sejarah yang ditambah analisis dan pengetahuan manejemen. Filosof Muslim dijadikan acuan dasar sebagai paradigma intihar manajemen yang berbasis kemanusiaan dan pola manusia.
\end{abstract}

Kata Kunci: Epistimologi, Filosof Muslim, Orientasi Manajemen Islam 


\section{Pendahuluan}

Pada umumnya, pembahasan tentang.epistimologi (teori pengetahuan) dimulai dengan penjelasan.tentang "sains" yang biasanya dibedakan dengan pengetahuan (knowledge). Tidak pernah jelas, misalnya apakah sains (science) itu sama atau berbeda dengan ilmu (ilm). Istilah ilmu terkadang dipandang sama dengan sains, tetapi kadang justru disamakan dengan knowledge atau "pengetahua n". Istilah ilmu pengetahuan juga terkadang dipakai untuk merujuk sanins yang dibedakan dengan pengetahuan (knowledge).

Mulyadhi Kartanegara (2003) mengatakan istilah ilmu dalam epistimologi Islam.mempunyai kemiripan dengan istilah science dalam epistimologi Barat.

Sebagaimana sains dalam epistimologi Barat dibedakan dengan knowledge, ilmu dalam epistimologi Islam dibedakan dengan opini ( $\left.r a^{\prime} y\right)$ sementara sains dipandang sebagai any organized knowledge, ilmu didedinisikan sebagai "pengetahuan.tentang sesuatu sebagaimana mestinya" (Al-Baqillani, 1970:53). Dengan demikian, ilmu bukan sembarangan pengetahuan atau sekedar opini, melainkan pengetahuan yang telah di uji kebenaranya. Pengertian ilmu sebenarnya tidak jauh berbeda dengan sains, hanya sains dibatasi pada bidangbidang fisik atau indrawi, ilmu melampauinya pada bidang-bidang non fisik seperti metafisika.

Karier dalam buku Scientists of the mind, mengkukuhkan bahwa pada masa-masa awal abad 19, sians dipaham sebagai "any organized knowledge" atau "sembarang pengetahuan yang teroganisasi", termasuk teologi.

Dalam konteks keislaman, ilmu merupakan awal subtansi manusia dalam membangun peradaban dunia. Ilmu menjadi dikotomi pola pikir manusia dalam menentukan trilogi ilmu pengetahuan yaitu pola pikir, pola ucapan dan pola implementasi sebagai bentuk amalan manusia dalam hasil ilmu pengetahuan secara episimologi. Hal ini termaktub dalam Imam Al-Buhkari Rahimahumullah membuat bab dalam kitab Shahihnya,"bab al-Ilmu Qablal Qaul Wal Amal".

Berilmu sebelum berkata dan beramal. Dalam substansinya ilmu adalah syarat sahnya suatu ucpaan dan perbuatan. Ucapan dan perbuatan tidak akan bermakna melainkan dengan ilmu. Ilmu lebih didahulukan dari keduanya (ucapan dan amal), karena ilmu akan meluruskan niat dan membenarkan amal (Ibnu Hajar, Fathul Bari, 1/160).

Pengertian dan pembahasan tentang "ilmu" (Ilm). "Ilm berasal dari 'alima yang artinya "mengetahui". Jadi, kata ilmu secara harfiah tidak berbeda dengan science yang berasal dari kata scire yang artinya "mengetahui" (Mulyadhi Kartanegara, 2003:4). Franz Rosental dalam knowledge triumphant (h.54) Ilmu ini didefinisikan, misalnya Ibnu Hazm, sebagai "pengetahuan tentang sesuatu sebagaimana adanya". Pengertian ilmu sebagaimana adanya mengsyaratkan bahwa ilmu tidak begitu saja sama dengan pengetahuan biasa karena pengetahuan biasa bisa saja tidak sebagaimana adanya, tetapi lebih sebagai pengetahuan umum yang dasarkan pada opini atau kesan keliru dari indra. Oleh karena itu, pengetahuan sebagaimana adanya mengisyaratkan.bahwa.pengetahuan tersebut haruslah.pengetahuan.yang telah.diuji.kebenaranya berdasarkan.bukti-bukti yang kuat dan tidak hanya.berdasarkan.praduga atau asumsi. Dengan demikian, ilmu memiliki kriteria yang memiliki oleh sains sebagai pengetahuan yang sistematis dan teroganisasi.

Ilmu memiliki ruang lingkup yang berbeda-beda dengan sains karena sementara sains hanya dibatasi dengan pada bidang-bidang empiris-positivisme, 
ilmu melampauinya dengan memasukan tidak hanya bidang-bidang empiris, tetapi juga nonempiris, seperti matematika dan metafisika. Pengertian "pengetahuan sebagaimana adanya" ini harus tetap berlaku, baik pada bidang fisik-empiris, matematika maupun metafisika.

Untuk mengetahui objek-objek empiris atau fisik sebagaimana adanya, para ilmuan muslim berusaha mengadakan penelitian yang seksama-melalui dan eksperimen-terhadap objek-objek tersebut seobjektif mungkin melalui, misalnya timbangan dan pengukuran. Kemudian, diciptakan sisren timbangan yang rumit dari pengukuran-pengukuran yang kompleks seperti yang dilakukan oleh AlBiruni (w. 1039). Untuk memperbaiki teori-teori ilmiah yang berkembang sebelumnya, para ilmuan Muslim melakukan beberapa kali eksperimen seperti yang dilakukan oleh Ibn Haitsam dalam kajianya tentang teori penglihatan atau vision, sebagaimana yang dia perikan sendiri dalam kitabnya, Al-Manazhir, atau observasi ilmiah seperti terhadap Nashr Al-Din Thusi dan Quthb Al-Din Syirazi di Maraghah (Toby Huff [The Rise of Early Modern Science], h.57). tentu saja, kegiatan ilmiah modern, kecuali bahwa teknis prosedur dan alat-alat atau instrumen ilmiah yang berakhir telah mengamali penemuan-penemuan yang spektakuler. Dengan demikian, prinsip dan sifat dasar dalam kegiatan ilmiah ilmuwan-ilmuwan Muslim dan modern tetap sama.

Pada awal ilmu dan sains mempunyai pengertian yang sama, bahkan juga lingkup yang sama. Kemudian sains membatasi diri pada dunia fisik dengan segala kompleksitasnya, sedangkan ilmu masih tetap meliputi tidak hanya bidang fisik, tetapi juga bidanng matematika dan metafisika. Opini, seperti yang telah disingung ialah pengetahuan umum atau sembarangan pengetahuan yang kebenaranya belum teruji melalui penelitian seksama (Mulyadhi Kartanegara, 2003:7).

Sering dikatakan bahwa ilmu sangat erat dengan ketidak pastian dengan agama, maksudnya ilmu tidak bertentangan dengan agama. Al-Qur'an mensinyalir adanya ilmu-ilmu yang bermanfaat dan tidak. Ilmu itu berkembang sesuai dengan ajaran-ajaran agama jelas tidak bertentangan. Ilmu yang dikembangkan tanpa menghiraukan Tuhan dan yang para pendukungnya.menolak.Tuhan.atas nama ilmu, itu perlu diwaspadai. Keilmuan Astronomi yang idak lagi menganggap perlu mengkaitkan alam dengan Tuhan karena Tuhan tidak riil.dan diambil.dalam penejlasan ilmiah hanya sebagai hipotesa semata. Untuk itu menurut Laplace dalam Mulyadhi Kartanegara (2003:67) mengatakan jelas bertentangan terhadap agama. Jadi, tidak semua ilmu bersifat positif atau suportif terhadap agama, bahkan ilmu yang.mempunyai prinsip yang bertentangan dengan prinsip.agama. Ilmu yang seperti itu jelas bertentangan dengan agama dan garus disikapi secara skritis.

Ali syari'ati (1998:16) seorang.intelektual Muslim "Raksasa" dari Iran berpendapat :"Science is knowledge.of man about the psyical world and its phenomena. It is man's mental image of the secret. It is the discovery of some relationship, of a principle, of quality, of a characteristic in man, in nature, or in other entities"

Dengan pendapat tersebut dapat disimpulkan bahwa pengetahuan manusia tentang dunia fisik dan fenomenanya. Sains merupakan gambaran mental manusia dalam menyikapi berbagai rahasia. Sains bertujuan untuk menentukan hubungan, prinsip-prinsip dan karakteristik tentang manusia, alam dan entitas-entitas lainya. Karena pengetahuan melalui metode sains (scientific methode), yakni atas.dasar 
observasi (bayani), percobaan dan demontrasi (burhani) serta intuisi (irfani), yang masing-masing bersumber pada indera, akal dan hati.

Dalam abad ke-20 ini tampak muncul.di negara-negara yang maju, suatu cabang ilmu.pengetahuan yang baru, yakni manajemen, yang bermula masih segan diakui sebagai ilmu pengetahuan. Hal seperti ini bukanlah suatu hal yang baru. Ilmu pengetahuan kemasyarakatan, yang sejak mula lahirnya dinamakan sosiologi, juga lama harus memperjuangkan kedudukannya disamping ilmu-ilmu pengetahuan yang lain yang sudah lebih lama berada. Seabad yang lalu, di masa Auguste Comte dan Herbert Spencer, ilmu sosiologi itu belum mendapat pengakuan sebagai ilmu, padahal kesarjanaan Spencer misalnya, tidak dapat diragu-ragukan: ia terkenal sebagai seorang ahli filsafat dan etika, ahli biologi dan sosiologi, dan terkenal karena belasan buku-buku tebal yang dikarangnya, tentang pengetahuannya yang luas itu. Mungkin pula disebabkan karena.kebisaan Inggris (tempat lahir dan hidupnya Spencer) yang mempunyai pengertian sempit itu maka bahasa, sejarah, politik dan ekonomi, yang dinamakan "humaniora" (pengetahuan tentang manusia), tidak termasuk di dalam Science!.

Demikian pula halnya dengan ilmu "manajemen" yang menjadi bahan perbincangan kita sekarang ini. Ilmu "manajemen" itu belum dianggap sebagai ilmu di masa Taylor dan.Fayol mulai memajukannya, bahkan dibagian negaranegara dewasa ini, orangf masih curiga dan ragu untuk mengajarkannya disebelah ilmu filsafat yang menurut para ahli cendekia, adalah ilmu yang tertua, dan ilmuilmu lainnya seperti ilmu alam, ilmu pasti, ilmu kedoktoran dan sebagainya. Seorang ahli. Epistemologi yang mampu mengintegrasikan cabang filsafat menelaah asal mulanya pengetahuan. Atau dapat juga dikatakan, epistemologi adalah apa yang menjadi pengetahuan, bagaimana karakter dan kebenaran pengetauan itu sndiri. Walhasil ia berada dalam tiga persolaan pokok yang menjadi pusat perhatiannya, yaitu:

1. Apakah yang menjadi sumber-sumber pengetahuan, dari manakah pengetahuan itu datang dan bagaimanakah kita dapat mengetahuinya. Inilah yang menjadi problem asal (origins problem) dari filsafat epistemologi;

2. Apakah karakter dari pengetahuan itu; adakah dunia yang nyata diluar akal manusia dan kalau ada dapatkah kita mengetahuinya. Inilah yang menjadi problem yang penampilan.(appearance problem) terhadap ralitas;

3. Apakah.pengetahuan kita.benar (valid); bagaimana kita.membedakan suatu kebenaran dengan suatu kekeliruan. Inilah yang menjadi problem memcoba suatu kebenaran.(verification problems) dari.pengetahuan sesuatu hal

Ilmu pengetahuan yang dipelihara-kembangkan oleh Institut Agama Islam dalam tatapan penulis sebagian berada pada epistemologi telaah klasik dan sebagian berada pada epistemologi telaah positivistik. Pendidikan Islam yang dipelihara-kembangkan di Institut Agama Islam lebih banyak dipengaruhi telaah epistemologi yang positivistik, dan sebagian kecil dipengaruhi telaah studi Islam klasik.

Penglihatan inderawi seseorang terhadap aktivitas kelompok dapat melahirkan kepengikutan individu atau aktivitas kelompok tanpa dilakukan pengkajian akal tentang benar tidaknya. Pengetahuan common sense, yang juga menjadi sumber pengetahuan. 
Ada empat common sense yang dipandang sebagai sumber pengetahuan, yaitu:

1. Pendapat orang awam yang condorong untuk bersifat kebiasaan dan meniru yang diwarisi dari masa silam. Ia bersandar pada adat dan tradisi, seperti upacara perkawinan yang harus dipersyarati dengan berbagai ketentuan yang tidak ada dalam ajaran agama.

2. Pendapat orang awam yang biasanya samar-samar dan tidak jelas. Pendapat ini dapat berbeda-beda dari orang ke orang lain, dari suatu daerah ke daerah berbeda-beda dari orang ke orang lain, dari suatu daerah ke daerah lain. Pendapat ini adalah campuran fakta dengan purbasangka, dari kebijaksanaan dan kecendurungan emosi. Ia mencakup pendapatpendapatyang terbentuk tanpa diteliti atau dikritik. Seperti fakta setiap orang-orang baik meninggal dalam usia muda.

3. Pendapat orang awam kebanyakan merupakan keprcayaan yang belum diuji. Seperti pendapat bahwa orang yang rambutnya merah bertempramen pemarah.

4. Pendapat orang awam jarang disertai dengan penjelasan mengapa hal itu terjadi, bagaimana terjadinya dan seterusnya. Jika ada penjelasan, sifat umum.

Keempat pendapat orang awam ini tidak serta merta harus ditolak kebenarannya oleh orang yang terjun ke dunia sains, tetapi hal ini harus dipertimbangkan dengan melakukan sistematisasi, pengujian berdasarkan bukti atas fakta-fakta sesungguhnya. Nagel (1961) menegaskan bahwa.yang menimbulkan sains adalah keinginan untuk menjelaskan yang bersifat sisyematis dan dapat di kontrol dengan bukti-bukti fakta; maksud yang jelas dari sains adalah untuk mengatur dan mengelompokkan atas dasar prinsip-prinsip yang menjelaskan.

Dengan demikian, penulis menyimpulkan ilmu pengetahuan dalam sains merupakan sumber ilmu yang memiliki karakteristik secara komfrehensif dan global sebagai pembuktian pola keilmuan dengan bertujuan untuk mengatur keilmuan secara sistematis.

Sementara itu, Osman Bakar, seorang Profesor Emeritus dalam filsafat Sains dan juga peneliti Senior di International Islamic University of Malaya, menegaskan bahwa Al-Qur'an merupakan sumber intelektualitas dan spritualitas. Ia adalah basis bukan hanya bagi agama dan pengetahuan spritual tetapu bagi semua jenis pengetahuan. Ia merupakan sumber utama inspirasi pandangan muslim tentang keterpaduan sains dan pengetahuan spritual (agama). Gagasan ini merupakan konsekuensi dari gagasan keterpaduan semua jenis pengetahuan, yang pada dasarnya diturunkan dari prinsip hakikat penciptaan manusia ke muka bumi.

Dengan demikian, tulisan ini bermaksud menyingkap bukti-bukti keterpaduan secara epistimologi yang termaktub dalam Manajemen Pendidikan Islam. Dan berusaha untuk mamaksimalkan paradigma manajemen yang dipandang sebagai bidang keilmuan dalam polasisasi keislaman. 


\section{Metodologi}

Penelitian pada hakekatnya, adalah suatu rangkaian langkah-langkah yang dilakukan secara terencana, dan sistematis untuk mendapatkan pemecahan masalah, atau mendapatkan jawaban terhadap pertanyaan-pertanyaan tertentu. Langkah-langkah yang dilakukan harus serasi, dan saling mendukung satu sama lain. Agar penelitian tersebut memiliki bobot yang memadai, dan memberikan hasil penelitian yang tidak meragukan. (Sumadi Suryabrata, Jakarta. 2006:11-12). Pendekatakan yang peneliti gunakan dalam penelitian ini, adalah menggunakan pendekatan kualitatif deskriptif analisis. Menurut Lexi. J. Moleong merujuk pendapat Bogdan dan Taylor, mendefinisikan metodologi kualitatif sebagai prosedur penelitian, yang menghasilkan data deskriptif berupa kata-kata yang tertulis, atau lisan dari orang-orang yang dapat diamati, (Lexi J. Moleong, 1989:3). Penelitian ini merupakan, penelitian kualitatif yang bersifat studi pustaka (library research). Menggunakan buku-buku dan literatur-literatur lainnya, sebagai objek yang utama, (Hadi, 1995: 3). Jenis penelitian yang digunakan, adalah kualitatif yaitu penelitian yang menghasilkan informasi berupa catatan, dan data deskriptif yang terdapat di dalam teks yang diteliti, (Mantra, 2008:30).

Adapun Jenis data yang digunakan dalam penulisan ini, ialah mengacu kepada dua sumber subjek antara lain: Sumber Primer, adalah data yang diperoleh langsung dari sumbernya, diamati dan dicatat untuk pertama kalinya. Sedangkan penelitian yang dilakukan, maka sumber primer yang dibutuhkan, ialah karyakarya yang ditulis langsung oleh penulisnya yang berhubungan dengan pendidikan Islam terhadap pemikiran Azyumardi Azra, berupa buku- buku, teks, dan karya ilmiah lainnya. Sumber sekunder, yaitu data yang bukan langsung dari sumbernya, tetapi data yang didapatkan peneliti untuk menguatkan data dari sumber primer, yang relevan dengan pembahasan penelitian. Data ini, mencakup kepustakaan yang bersifat buku-buku penunjang, jurnal dan karya-karya ilmiah lainnya. Yang ditulis, atau diterbitkan oleh studi selain bidang yang dikaji, yang membantu penulis berkaitan dengan pemikiran yang dikaji (Suharsimi, 2006:26).

\section{Paradigma Manajemen Islami}

Askioma yang menyatakan bahwa kita harus berislam secara utuh dan menyeluruh. Jadi pengetahuan dan peraktik manajemen mestinya harus berlandaskan Islam pula. Islam merupakan agama yang telah disempurnakan. Laa yanqushuhu abadan, wa laa yahtaju ilaa ziyadatin abadan. Artinya, tidak akan berkurang dan tidak perlu tambahan selama-lamanya (Al-Syanqithi, $1914 \mathrm{H:}$ 3). Konsekwensinya seorang menejer haruslah orang yang bertakwa. Bertakwa sendiri pengertianya merupakan ketakutan kepada Allah, berhati-hati dalam mengambil keputusan karena khawatir mendapatkan dosa.

Ada garis sifat manajemen Sumber.Daya Manusia pada berbagai lembaga dan bidang. Manajemen merupakan fungsi genetik segala organisasi apapun misinya (Dimitri Mahayana, 1999: 42). Definisi baru Manajer dalam Knowledge society adalah; a manager is responsible for the application and performance of knowledge (Loc Cit).

Menejemen Sumber Daya Manusia di lembaga manapun, dapat ditransfer dalam organisasi lain. Seperti Manajemen Sumber Daya Manusia (SDM) di pemerintahan, pendidikan, politik, ekonomi dll. Di samping itu para pakar yang menyatakan bahwa manajemen digunakan dalam segala bentuk kegiatan profesi 
maupun non profesi, baik organisasi pemerintah;maupun swasta (Musa Hubeis, 2007).

Indonesia sebagai salah satu negara yang menerapkan sistem pemerintahan memiliki tanggung jawab penuh terhadap pendidikan. Kementerian Pendidikan dan Kebudayaan serta Kementerian Agama. menjadi.tolak ukur signifikan dalam perkembangan.berbangsa dan bernegara. Dalam fungsi manajemen, Kementerian memiliki manajerial utuh terhadap perkembangan dan perbaikan sistem dalam menghadapi globalisasi. Perkembangan.zaman yang cepat, sangat menuntut lembaga pemerintah untuk memperbaiki pengawasan serta peran sebagai otoritas tangung jawab kepada negara. Dengan demikian, pentingya membangun sistem informasi menjadi salah satu solusi untuk.membangun mutu manajerial secara efektif.

Ditemukan jurang dan jarangnya keteladanan dalam manajemen di semua bidang. Sehingga dapat dibilang manusia telah mabuk teori, tetapi haus keteladanan. Menurut kenyataan, persoalan prinsip manusia bersifat eternal alias tetap. Sebagai contoh, sepuluh ribu.tahun mendatang, seorang gadis akan tetap mengalami kesulitan mencari suami yang baik. Persis seperti keteladanan saat ini, dan ,orang masih tetap akan mengalami sakit dan mati, dan mereka tatap kecewa (Issac Bashevis Singer, 1979: 35).

Dengan demikian, substansi paradigma manajemen merupakan sebuah metamorfosa. Metamorfosa sejarah yang ditambah.analisis dan pengetahuan manejemen. Karena bagaimanapun juga, isi utamanya diambil dari sejarah hidup manusia. Bahkan manusia yang sudah sangat akrab di hati manusia itu sendiri. Seorang yang biasa dalam kemanusiaan, tetapi istimewa dalam keteladanan. Seorang manusia biasa daging dan tulang. Tetapi berbeda dengan kualitas, yaitu Muhammad shallahu alahi wasallama (Muchotob Hamzah, 2008: v).

Hal ini ditangkap oleh filosof Muslim untuk dijadikan acuan dasar sebagai paradigma intihar manajemen yang berbasis kemanusiaan dan pola manusia.

Pengalaman di lapangan saat ini cukup memperhatinkan. Banyak para manajer yang terkena penyakit hipokondriasis. Baik dalam bidang perusahaan, lembaga pendidikan, politik mapun pemerintahan. Masyarakat kita telah mengidap penyakit ini. Penyakit politico hipocondraiasis, sosio hipocondraiasis, religio hipocondraiasis, dan utamanya economico hipocondraiasis (Muchotob Hamzah, 2008).

Dengan demikian masyarakat yang membenarkan adanya kekotoran dalam manajemen. Kekotoran dalam kepemimpinan, dalam politik, pendidikan dan sosial. Kata orang "manajemen harus kotor. Politik harus kotor. Ekonomi harus kotor". Mereka menghalalkan kekotoran dalam permainan dunia ini. Hal ini sangat riskan dilakukan dalam era maju seperti saat ini. Semua dapat di minimalisasi terhadap aspek kekotoran yang telah dilakukan oleh sebagian orang, dengan hepotesa yang tidak terdasar dalam epistimologi manajerial.

Secara epistimologi Islam, manajemen telah diasumsikan oleh para pemikir malalui nasab secara perennial dan sistematis. Manajerial handal telah diucapkan melalui lisan Nabi Mahammad Shallahu Alaihi Wasallama ialah sebagai berikut:

"Aku, Muhammad bin Abdulllah bin Abdul Muttalib. Sesungguhnya Allah telah menciptakan mahkluk, maka Dia menjadikan mereka dua bagian, maka Dia menjadikan aku dalam bagian yang terbaik.di antara.dua bagian itu. Kemudian Dia menjadikan mereka beberapa suku, maka Dia 
menjadikan aku dalam suku terbaik.diantara.suku-suku itu. Kemudian Dia menjadikan mereka beberapa keluarga, maka Dia menjadikan aku dlaam keluarga dan nasab terbaik di antara keluarga-keluarga itu" (H.R. At-tirmidzi no. 3532, Kitab ad-Da'awat. Hadis itu hasan dalam Shahih aw Da'if Sunan at-Tirmidzi).

Dengan demikian, manajemen Nabi Muhammad Shallahu Alaihi Wasallama merupakan langkah manajemen strategis (Erwin FS,Republika, 25/3/2008). Hal itu diungkapkan ketika beliau menerapkan etika bisnis dengan kejujuran sedemikian tingginya, beliau sempat membangun kerajaan bisnis multinasional.

Kemudian, pada saat Nabi Muhammad Shallahu Alaihi Wasallama menerima perjanjian Hubaidiyah yang sepintas merugikan umat Islam, itupun beliau menerapkan manajemen strategis. Sebab beliau melihat peluang ke depan yang jatuh untuk kemenangan Umat Islam. Ketika beliau menerima ide Salman Al-Farisi membangun parit untuk melindungi Madinah dari seragam kaum Musyrikin, itupun menerapkan manajemen strategis. Implementasi lebih lanjut dari manajemen strategis beliau.ialah membangun kompetensi inti kaum muslimin di berbagai sektor dan lini. Dengan demikian strategis.ialah intrumen penting dalam menjadikan manajemen sebagai langkah strategis untuk menjadikan epistimologi manajemen pada bidang keislaman.

Pada dasarnya, yang menjadi tema utama dalam teori kompleksitas telah dipelajari selama lebih dari seratus tahun oleh fisikawan yang berevolusi dengan menggunakan alat kit konsep dan teknik studi yang kompleksitas telah menambahkan hampir beberapa item baru. Teori kompleksitas menawarkan beberapa wawasan yang berguna ke dalam sifat kontinuitas dan perubahan.

Dengan demikian cukup menarik di kedua pemahaman filosofis dan praktis dari perubahan pendidikan dan kelembagaan. Gagasan Kompelsitas teori tentang munculnya bahwa mengingat tingkat signifikan kompleksitas dalam linkungan tertentu, atau massa kritis, sifat dan prilaku baru muncul yang tidak terkandung dalam esensi.dai unsur, atau dapat diprediksi dari pengetahuan tentang awal kondisi (Mark Mason, 2008).

Pada mulanya manajemen belum dapat dikatakan sebagai teori, karena teori harus terdiri dari konsep-konsep yang secara sistematis dapat menjelaskan dan meramalkan apa yang akan terjadi dan membuktikan ramalan itu berdasarkan penelitian. Setelah dipelajari selama beberapa zaman, manajemen telah memenuhi persyaratan sebagai bidang pengetahuan secara sistematik berusaha memahami mengapa dan bahaimana orang-orang bekerja sama. Menurut Luther Gulick (1965) mengungkapkan bahwa menejemen telah memenuhi syarat sebagai ilmu pengetahuan karena memiliki serangkaian teori, meskipun teori-teori itu masih umum dan subjektif. Manajemen merupakan perjalanan suatu bidang keilmuan, teori-teori manajemen yang ada diuji dengan pengalaman.

Dengan demikian paradigma manajemen telah dibuktikan dari pola pikir manajemen menjadi suatu ilmu yang mampu menuntun manajer dengan memberikan penjelasan apa yang harus dilakukan pada situasi tertentu serta meramalkan akibat-akibat dari tindakanya.

\section{Epistimologi Manajemen Islam}

Upaya untuk mengabungkan pemikiran Islam dengan pemikiran Yunani mendominasi kehidupan intelektual sepanjang kekhalifahan Bani Umayyah dan 
Bani.Abbasiyah. Ilmuan yang berhubungan dengan Kristen Nestoris yang bersala dari Hira (sebuah kota kecio anatara basrah, Kufah dan Mesopotamia Selatan). Kontrovensi.terjadi setelah diperkenalkan karya-karya sains dan filsafat Yunani pada pertengahan abad ke delapan. Sehingga muncullah gerakan-gerakan dan kelompok yang sisebut Qasariyah. Dengan menggunakan metode rasional Yunani, ilmuwan Hira berusaha menggabungkan akal dan wahyu. Khalifah Bani Umayyah, Muawiyah II (683-684 M) dan Yazid III (744 M) adalah pengikut aliran Qadariyah (Charles Michael Stanton, 1990: 92-93).

Telah diketahui banyak ahli, sejak dahulu para filosof telah bermimpi. Impian ini dalam manajemen sekarang disebut Visi. Sebagai.visioner para filosof menyebut Negara.Utama. Dalam bahasa filosof Al- Farabi disebut al-Madinat alFadhilah. Dalam bahasa sebagian filosof Yunani disebut Republika. Negara yang gemah ripah lon jinawi, kata orang jawa. Dalam bahasa Al-Quran.disebut Baldatun Thayyibatun wa Rabbun Ghafur (Muchotob Hamzah, 2008: 14).

Muhammad Al-Ghazali.berani menyatakan impian filosof itu telah terwujud.pada negara.Madinah (Muhammad.Al-Ghazali, 270). Piagam Madinah dengan segala Hard Ware, Soft Ware dan Human Ware-nya memenuhi kriteria impian filosof.

Dengan demikian, untuk mengindentifikasi dapat ditangkap dari pernyataan para ahli di Barat. Mereka adalah orang-orang Non Muslim. Perynyataan ini banyak komentar terhadap Manajerial negara Madinah. Sebuah Negara yang dikenal dengan Civil.Society (masyarakat santun).

Para filosof mengakui, tidak saja penalaran rasional dan pengalaman mistik sebagai sumber ilmu, tetapi juga kenabian atau wahyu. Dalam kitabnya $A l$ Asfar Al-Arba'ah, Mulla Shadra menyebut ketiga sumber tersebut.sebagai burhan (demonstrative proof), 'irfan (gnosis, ma'rifah) dan Qur'an (wahyu dan kenabian).

Pada masa Al-Farabi.dan Ibnu Sina, teori kenabian merupakan fenomena baru yang khas islami karena tidak ditemukan teori-teori kenabian ini, misalnya, dalam karya-karya filosof Yunani pra-Islam. Oleh karena itu, teori-teori yang dihasilkan oleh para filosof Muslim merupakan wujud nyata dari tanggung jawab moral mereka untuk menjelaskan secara rasional dogma-dogma ajaran Islam yang mereka anut, dan di sini juga kita melihat kontribusi mereka yang signifikan pada khazanah kelimuan Islam karena teori-teori tersebut merupakan.kresi-kreasi mereka yang orisinil (Mulyadhi kartanegara, 2003: 103-104).

Objek yang dikaji ilmu manajemen adalah fakta dan realitas. Objek yang dikaji adalah keteraturan dengan menggunakan sejumlah instrumen yang membenarkan kereraturan itu sendiri. Namun, keteraturan sebagi fakta tidak selalu menjadi suatu realitas yang mengejar nilai-nilai yang menjadi energi dan motivasinya. Keteraturan dengan efisiensi yang diharapkan kadangkala melahirkan hal yang inefesien, dan itulah realitas. Pada setiap lokus yang dikembangkan oleh keteraturan, fakta dan realitas saling bermain dalam keteraturan itu sendiri, sehingga jika kita menempatkan keteraturan dalam lokus keadilan misalnya, keteraturan yang dicapai adalah keteraturan yang adil. Seperti manajemen melakukan pengaturan tentang pemerataan, pada akhirnya yang diperoleh adalah ketidakadilan, sebab bagimana mungkin kita menerapkan prinsip pemerataan di anatar realitas yang heterogen. Begitu pula, ketika menghendaki keteraturan lewat pemberdayaan, kita harus mengenyahkan nilai-nilai efisensi, nilai yang dikembangkan secara universal oleh ilmu manajeman. 
Rasulullah Shallahu Alaihi Wasallama adalah pengemban Al-Qur'an sebagai perjanjan terakhir (Last Testament), sebelumnya sudah ada/perjanjian lama, Taurat (Old Testament) dan perjanjian baru, Injil (New Testament). Maka beliau dibekali ilmu yang mencakup segala kebutuhan manusia. Tentu keilmuanya bersifat global, kecuali bidang idabah mahdhah. Di antaranya ialah ilmu manajemen. Pada dataran ilmu ini, Rasulullah Shallahu Alaihi Wasallama selalu mengacu pada Al-Qur'an.

Adapun karakteristik dalam manajemen islami ialah sebagai berikut:

1. Kebijakan mutlak (Al-Khairat al-Muthlaqah)

2. Kemashalatan umum (Al-Shilahiyyat al-Ammah)

3. Konsisten (Al-Tsabat)

4. Kewajiban yang ditaati (Al-Ihzam al-Muthi'ah)

5. Pengawasan komprehenshif (Al-Riqabat al-Muhithah) (Muchotob Hamzah, 2008: 15-17).

Al-Qur'an sebagai sumber keilmuan, memiliki unsur.kontruktivisme dalam epistimologi manajemen Islam yang telah termaktub beberapa bagian sebagai landasan dasar keilmuan manajemen, ialah sebagai berikut:

1. Faktor Profesionalisme

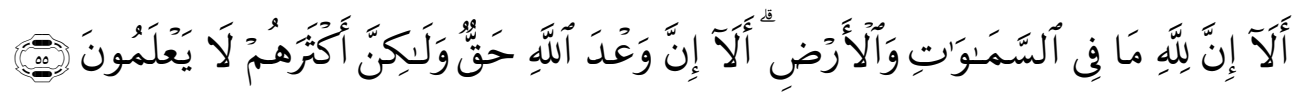

Artinyna: "Ingatlah, Sesungguhnya kepunyaan Allah apa yang ada di langit dan di bumi. Ingatlah, Sesungguhnya janji Allah itu benar, tetapi kebanyakan mereka tidak.mengetahui-Nya".

Dan seraya hal itu Rasulullah Shallahu Alaihi Wasallama bersabda "barang siapa yang menyerahkan kepada yang bukan ahlinya, maka tunggulah kehancuran".

Dengan demikian, pola manajerial Islam menentukan pengaturan dalam merencanakan pola profesionalisme yang diciptakan pada profesi manajemen itu sendiri pada.setiap individu sebagai hak manusia untuk mendapatkan harakah profesional dalam dirinya.

Profesi.adalah suatu.pekerjaan yang menuntut persyaratan tertentu. Persyaratan suatu profesi menghendaki berbagai kompetensi sebagai dasar keahlian khusus, diakui dan dihargai oleh masyarakat dan pemerintah, dan memiliki kode etik (Nanang Fattah, 2009: 3).

Untuk itu, manajemen Islam tidak terhindar dalam sebuah keabstrakan dalam menentukan identitas keahlian dalam bidang ilmu manajerial, karena AlQur'an telah membuktikan dalam epistimologi keilmuan bahwa Islam sangat memiliki integritas dalam membangun serta merancang manusia untuk menjadikan manusia itu sebagai manusia yang profesional dan memiliki profesi khusus sesuai dengan persyaratan tertentu.

2. Faktor Manajerial

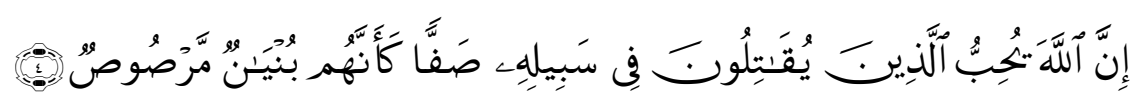

Artinya: "Sesungguhnya Allah menyukai orang yang berperang dijalan-Nya dalam barisan yang teratur seakan-akan mereka seperti.suatu bangunan yang tersusun kokoh". 
Seorang harus memiliki ilmu managerial meskipun dalam standar yang minim memahami manajemen kepemimpinan, perencanaan, administrasi dan distribusi keangotaan. Pemimpin harus mampu menciptakan keserasian, keharmonisan dan kerapian dalam lembaga (tandhim), baik aturan aturan anggota pencapaian hasil, serta parameter parameternya.

Dengan kemampuan ini, maka terciptanya tanasuq (keteraturan), tawazun (keseimbangan) yang semuanya bermura pada takamul (komfrehensif) secara keseluruhan.

Eksistensi kebenaran pada manajemen ilmu pendidikan Islam yaitu eksistensi sensual, logik, etik, dan transedent yang paralel dengan 'ayah, isyarah, hudan, dan rahmah. Filsafat yang secara eksplisit mengakui yang transedent adalah phenomenologi dan reaslisme metaphisik. Filsafat yang secara implisit mengakomodasikan yang etik dan transedent adalah rasionalisme.

Dilihat dari postulasi aksiologiknya manajemen ilmu pendidikan Islam itu ilmu normatif, sehingga perlu dan harus diorientasikan kepada nilai atau "values" baik yang insaniyah (berkembang bersama budaya manusia) dan yang Ilahiyah (diwahyukan). Filsafat yang diketengahkan pada postulasi ontologik. Dan untuk nash, model logika refleksi probabilistik dengan terapan tematik atau maudhu'i lebih tepat digunakan.

\section{Kesimpulan}

Ilmu memiliki ruang lingkup yang berbeda-beda dengan sains karena sementara sains hanya dibatasi dengan pada bidang-bidang empiris-positivisme, ilmu melampauinya dengan memasukan tidak hanya bidang-bidang empiris, tetapi juga nonempiris, seperti matematika dan metafisika. Pengertian "pengetahuan sebagaimana adanya" ini harus tetap berlaku, baik pada bidang fisik-empiris, matematika maupun metafisika.

Dalam konteks keislaman, ilmu merupakan awal subtansi manusia dalam membangun peradaban dunia. Ilmu menjadi dikotomi pola pikir manusia dalam menentukan trilogi ilmu pengetahuan.yaitu pola pikir, pola ucapan dan pola implementasi sebagai bentuk amalan manusia dalam hasil ilmu pengetahuan secara episimologi.

Ilmu pengetahuan.dalam sains merupakan sumber ilmu yang memiliki karakteristik secara komfrehensif.dan.global sebagai pembuktian pola keilmuan dengan bertujuan untuk mengatur keilmuan secara sistematis.

Substansi paradigma manajemen merupakan sebuah metamorfosa. Metamorfosa sejarah yang ditambah analisis dan pengetahuan manejemen. Karena bagaimanapun juga, isi utamanya diambil dari sejarah hidup manusia.

Paradigma manajemen telah dibuktikan dari pola pikir manajemen menjadi suatu ilmu yang mampu menuntun manajer dengan memberikan penjelasan apa yang harus dilakukan.pada situasi tertentu serta meramalkan akibat-akibat dari tindakanya.

Objek yang dikaji ilmu manajemen adalah fakta dan realitas. Objek yang dikaji adalah keteraturan dengan menggunakan sejumlah instrumen yang membenarkan kereraturan itu sendiri Objek yang dikaji ilmu manajemen adalah fakta dan realitas. Objek yang dikaji adalah keteraturan dengan menggunakan sejumlah instrumen yang membenarkan kereraturan itu sendiri.

Manajemen Islam tidak terhindar dalam sebuah keabstrakan dalam menentukan identitas keahlian dalam bidang ilmu manajerial, karena Al-Qur'an 
telah membuktikan dalam epistimologi keilmuan bahwa Islam sangat memiliki integritas dalam membangun serta merancang manusia untuk menjadikan manusia itu sebagai manusia yang profesional dan memiliki profesi khusus sesuai dengan persyaratan tertentu.

Eksistensi kebenaran pada manajemen ilmu Islam yaitu eksistensi sensual, logik, etik, dan transedent yang paralel dengan 'ayah, isyarah, hudan, dan rahmah. Filsafat yang secara eksplisit mengakui yang transedent adalah phenomenologi dan realisme metaphisik. Filsafat yang secara implisit mengakomodasikan yang etik dan transedent adalah rasionalisme.

\section{Daftar Pustaka}

Bahrun Rangkuti, Kepemimpinan Nabi Muhammad SAW, Jakarta: Agus Salim, 1956.

Charles Michael Stanton, Higher Learning of Islam: The Classical Periode A.P. 700-1300, Meryland: remand and Littlefield Publisher, 1990.

Ernest Nagel, The Structure of Science, New York: Harcourt, Brace and World, 1961.

Erwin FS, Manajemen Muhammad saw, Jakarta: Republika, 25 Maret 2008.

Fren Rosental, Knowledge Triumphant: The Concept of Knowledge in Medical Islam (Leiden:E.J. Brill,) 2009.

Jujun S. Suriasumantri, Ilmu dalam Perspektif, Jakarta: Yayasan Obor Indonesia, 1999.

Luther Gulick, Management Is A science, Jounal: No. 8 Maret 1965.

Nanang Fattah. Landasan Manajemen Pendidikan, Bandung: PT Remaja Rosdakarya. 2008.

Nasr, Science and Civilation in Islam (New york: American Library) 1968.

Noeng Muhadjir, Epistemologi Pendidikan Islam Pendekatan Teoritik-Filosofik, Majalah ilmiah Khazanah, Banjarmasin: IAIN Antasari Banjarmasin, 1994.

Muhammad al-Amin al-Syanqithi, Al-Islam Diinun Kaamilun, Daar Wathan, Riyadh, $1419 \mathrm{H}$.

Muchotob Hamzah, Managing By Examples (sukses Rasul Memanaj Ummah dan Daulah), Narasi Unggul, Wonosobo: 2008.

Muhammad Al-Ghazali, Fiqhus-Sirah, terj. Bandung: Al-Ma'rif.tt

Musa Hubeis, Prof.Dr.Ir,MS,Ing,DEA, Dasar-dasar Manajemen Indrustri, Inti Prima, Utan Kayu Raya, Jakarta: 2007.

Mark Mason, Complexity Theory and the Philosophy of Education, Wiley Blackweel, 2008.

Mulyadhi Kartanegara, Menyibak Tirai Kejahilan Pengantar Epistemologi Islam, Bandung: Mizan Media Utama (MMU), 2003.

Muyadhi Kartanegara, Menembus Batas Waktu: panorama Filsafat Islam, Bandung: Mizan, 2002. 